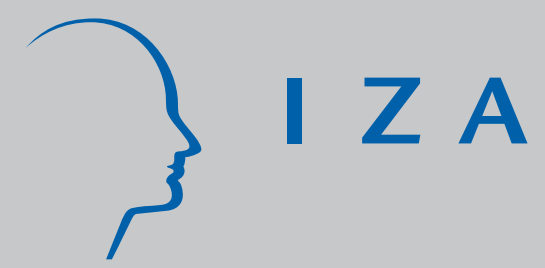

IZA DP No. 8122

Unaffordable Housing and Local Employment Growth: Evidence from California Municipalities

Ritashree Chakrabarti

Junfu Zhang

April 2014

Forschungsinstitut zur Zukunft der Arbeit Institute for the Study of Labor 


\title{
Unaffordable Housing and Local Employment Growth: Evidence from California Municipalities
}

\author{
Ritashree Chakrabarti \\ IHS Global Insight \\ Junfu Zhang \\ Clark University \\ and IZA \\ Discussion Paper No. 8122 \\ April 2014 \\ IZA \\ P.O. Box 7240 \\ 53072 Bonn \\ Germany \\ Phone: +49-228-3894-0 \\ Fax: +49-228-3894-180 \\ E-mail: iza@iza.org
}

\begin{abstract}
Any opinions expressed here are those of the author(s) and not those of IZA. Research published in this series may include views on policy, but the institute itself takes no institutional policy positions. The IZA research network is committed to the IZA Guiding Principles of Research Integrity.

The Institute for the Study of Labor (IZA) in Bonn is a local and virtual international research center and a place of communication between science, politics and business. IZA is an independent nonprofit organization supported by Deutsche Post Foundation. The center is associated with the University of Bonn and offers a stimulating research environment through its international network, workshops and conferences, data service, project support, research visits and doctoral program. IZA engages in (i) original and internationally competitive research in all fields of labor economics, (ii) development of policy concepts, and (iii) dissemination of research results and concepts to the interested public.
\end{abstract}

IZA Discussion Papers often represent preliminary work and are circulated to encourage discussion. Citation of such a paper should account for its provisional character. A revised version may be available directly from the author. 


\section{ABSTRACT \\ Unaffordable Housing and Local Employment Growth: Evidence from California Municipalities ${ }^{*}$}

It is widely believed that unaffordable housing could drive businesses away and thus impede job growth. However, there is little evidence to support this view. This paper presents a simple model to clarify how housing affordability is linked to employment growth and why unaffordable housing could negatively affect employment growth. The paper then investigates this effect empirically using data on California municipalities. For various reasons, a simple correlation between unaffordable housing and employment growth cannot be interpreted as causal. Several empirical strategies are employed to identify the causal effect of unaffordable housing on employment growth. The estimation results provide consistent evidence that unaffordable housing indeed slows local employment growth. Policy implications of these findings are briefly discussed.

JEL Classification: R11, R12, R13

Keywords: $\quad$ housing affordability, employment growth, amenity, California

Corresponding author:

Junfu Zhang

Department of Economics

Clark University

950 Main Street

Worcester, MA 01610

USA

E-mail: juzhang@clarku.edu

\footnotetext{
* This paper was completed when Zhang was a visiting scholar at the New England Public Policy Center at the Federal Reserve Bank of Boston. We thank Nate Baum-Snow, Eric Brunner, and Vernon Henderson for stimulating discussions on this topic. This paper has also benefited from comments by John Brown, Jackie Geoghegan, Jed Kolko, Gunther Maier, Alicia Sasser, Jenny Schuetz, Jeff Zabel, several anonymous referees, and seminar participants at AIER, the Boston Fed, Clark, UMass Dartmouth, the Econometric Society Summer Meetings, the North American meetings of the RSAI, and the 2010 ASSA annual meetings.
} 


\section{Introduction}

Housing prices and their growth rates vary substantially across regions in the United States. For example, the median sales price of single-family homes in the San Francisco area was $\$ 805,400$ in 2007 , compared with a median price of $\$ 130,000$ in the Cleveland area. According to the S\&P/Case-Shiller Home Price Index, home values appreciated by 354 percent in San Francisco from January 1987 to January 2007, whereas they rose only 122 percent in Cleveland. ${ }^{1}$

In regions where housing prices are relatively higher or grow faster, there are always concerns that unaffordable housing could adversely affect local economic growth. (See Box 1 for quotes from newspaper articles reflecting widespread anxiety over high housing prices in California and other regions of the country.) There appears to be a general belief that high housing prices increase the costs of living and doing business, make a region less attractive to workers and businesses, and therefore hurt the regional economy by slowing down employment growth. However, there is little empirical evidence that supports such a belief.

Fast-growing housing prices until 2006 inspired many studies on local housing markets in the United States, mostly focusing on the supply side. ${ }^{2}$ Glaeser, Gyourko, and Saks (2006) find that in metropolitan areas with more stringent land-use regulations, positive labor demand shocks lead to slower population growth and faster housing price appreciation. Gyourko, Mayer, and Sinai (2013) show that inelastic land supply in some attractive locations, combined with the growing number of high-income families nationally, can partially explain the growing differences in house prices and incomes among cities. This line of research has helped us better understand why housing price varies so much across regions, but it does not directly address the question how high housing prices would affect local employment growth.

\footnotetext{
${ }^{1}$ See data on housing prices for U.S. metropolitan areas at http://www.realtor.org/research/research/metroprice and data on the S\&P/Case-Shiller Home Price Index for U.S. metropolitan areas at http://www.data360.org/issue group.aspx?Issue_Group_Id=12.

2 The bulk of this literature focuses on how land-use regulations restrict land supply and in turn lead to higher housing prices. See, for example, Glaeser (2006), Glaeser and Gyourko (2003), Glaeser, Gyourko, and Saks (2005a, 2005b), Glaeser and Ward (2009), Ihlanfeldt (2007), and Quigley and Raphael (2005). Hwang and Quigley (2006) examine how a broad range of economic conditions and regulations affect the outcomes in local housing markets.
} 
Some earlier research has examined the interactions between local housing and labor markets. Bover, Muellbauer, and Murphy (1989) show that inter-regional differences in house-price-to-earnings ratios are correlated with regional unemployment in the United Kingdom. Using data from the Southeast region of the United Kingdom, Johnes and Hyclak (1994) estimate a system of equations to assess the role of housing price in short-run regional adjustments of unemployment. Using data from four U.S. metropolitan areas, Johnes and Hyclak (1999) estimate an error correction model to show that housing price has a significant effect on the size of local labor force.

More recently, Saks (2008) and Zabel (2012) have made significant contributions to this literature. Saks (2008) investigates how housing supply regulations affect housing and labor market dynamics in metropolitan areas across the United States. She argues that land-use and other government regulations can lower the elasticity of housing supply, which in turn can change the geographic distribution of housing prices and alter the pattern of labor migration. As a result, employment growth will be lower in places where the housing supply is more constrained. Saks presents some empirical evidence that supports this hypothesis. Along the same line of research, Zabel (2012) estimates a richer model that incorporates in- and out-migration as well as spillover effects among nearby cities. He finds that positive demand shocks tend to produce more in- and outmigration and thus more churning of workers in high-housing-cost areas, but the resulting employment and wage increases are similar between high- and low-housing-cost areas.

The present paper differs from the existing literature in two respects. First, it directly addresses the question raised by local policymakers. Despite the concerns voiced in the popular media, little research focuses narrowly on the effect of unaffordable housing on local employment growth. The existing studies are motivated by broader questions such as how labor and housing markets are interconnected and how a local economy responds to labor market shocks. In contrast, this study seeks to answer the very specific question: If housing is less affordable in a city, is employment growth going to be slower? Second, and more importantly, this paper confronts the identification problem directly and offers a theory-based solution. In empirical research, exogenous sources of variations are crucial for identifying the effect of one endogenous variable on another and such variations are difficult to find. Earlier studies in this literature make 
little effort to justify the choice of exogenous variables in model estimation. Saks (2008) and Zabel (2012) pay more attention to this problem. Following Bartik (1991), they measure labor demand shocks using a weighted average of national industry employment growth where the weights are given by the industrial composition of the local economy. Saks (2008) goes further by interacting this Bartik measure of labor demand shocks with an index of local housing supply regulation to make the exogeneity assumption more plausible. The Bartik measure, although rather commonly used, is an ad hoc formulation. In contrast, this study will propose a theory that not only explains why unaffordable housing may affect local employment growth, but also provides a candidate instrumental variable for estimating this effect. Therefore, the identification strategy in this paper ties more closely to the underlying theoretical framework.

This study has two objectives. First, to develop a simple model to clarify why housing affordability varies among cities, and under what conditions unaffordable housing could have negative effects on local employment growth. The model reveals two insights: (1) Different levels of amenities in different cities drive the variation in housing affordability; and (2) cities with unaffordable housing could experience slower employment growth, because land rents are so high in those cities that they have already reached the very inelastic portion of their land supply curves.

Second, to test whether unaffordable housing indeed negatively affects employment growth. Data on California municipalities are used to empirically measure the effects of unaffordable housing on employment growth. Given the potential simultaneity and omitted-variables problems in OLS regressions, climate amenity variables are used to instrument for housing affordability, a solution suggested by the theoretical model.

The next section outlines the theoretical framework. The ensuing section discusses empirical specification and identification strategies. The rest of the paper describes data sources and presents empirical results before concluding.

\section{Theoretical Framework}

This section presents a simple model to clarify thinking and motivate empirical research. The starting point is a simplified version of the well-known Roback (1982) 
model, which uses variations in amenities at the city level to explain differentials in land rents and income across cities. Some explicit assumptions are then made about land supply in different cities, which within the Roback-type framework imply a relationship between housing affordability and local employment growth.

Consider an economy that consists of many cities, each endowed with some amenity level $a$. One could think of the amenity as the total number of sunny days in a year, or the average daily temperature in winter.

City residents are all workers. A representative worker consumes a composite good $x$ and land $s$ (lot size, as part of housing), and enjoys the amenity $a$. He has the following utility maximization problem:

$$
\begin{aligned}
& \operatorname{Max} U(x, s, a), \\
& \text { s.t. } x+r s=w+m,
\end{aligned}
$$

where $r$ is land rent; $w$ is wage income; and $m$ is non-labor income. The price of the composite good is determined on the international market. It is used as the numeraire and normalized to 1 . To keep notation clean, city indexes are suppressed here. However, it should be noted that $a, r$, and $w$ all vary across cities.

Equation (1) defines the representative worker's indirect utility function $V(w, r$, a). ${ }^{3}$ Assume that workers can freely move from one city to another at no cost. In equilibrium, every worker would attain the same level of utility $u$ :

$$
V(w, r, a)=u \text {. }
$$

$V$ increases with $a$ and $w$ and decreases with $r$. That is, $V_{a}>0, V_{w}>0$, and $V_{r}<0$.

There are also firms located in these cities. All firms have access to the same technology, which uses land and labor to produce the composite good. The production function is written as $f(n, d)$, where $n$ is the number of workers and $d$ is the quantity of land used in production. Following Roback (1982) and subsequent literature, the analysis here ignores any capital used in production. Alternatively, one could admit the use of capital, but assume a fixed capital-to-labor ratio (such as one computer for each worker). In that case, as long as the price of capital is not determined locally, the production function can still be written this way without an explicit capital input.

\footnotetext{
${ }^{3}$ One could assume that the central government collects all the land rent and distributes it equally among all citizens in the form of non-labor income. Because non-labor income is the same for everybody, it does not show up explicitly in the indirect utility function.
} 
Assume that function $f$ exhibits constant returns to scale. Then the production technology can be represented using the unit cost function $C(w, r)$, which gives the minimum cost of producing one unit of good $x$. Firms are free to enter or exit the market, and can move costlessly from one city to another. This implies that in equilibrium firms everywhere have the same unit cost, which equals output price:

$$
C(w, r)=1
$$

Note that $C_{w}>0$ and $C_{r}>0$.

Workers consume land only as part of housing. Housing here refers to a physical structure attached to a piece of land. For simplicity, assume that every worker lives in the same kind of physical structure, which is produced and assembled on the international market. Therefore, the physical structure is just as part of the composite good $x$. Let $b$ be the amount of the composite good that constitutes the physical structure of housing, and assume that in equilibrium, $b<<x$ for any worker. A worker's spending on housing is therefore $b+r s$. Following common practice, housing affordability is measured using the ratio of housing price to labor income:

$$
h=(b+r s) / w .
$$

A higher $h$ implies that housing is less affordable. ${ }^{4}$

Next, examine how $h$ varies from one city to another. Differentiating equations (2) and (3) with respect to $a$ yields:

$$
\begin{aligned}
& d w / d a=V_{a} C_{r} /\left(V_{r} C_{w}-V_{w} C_{r}\right)<0, \text { and } \\
& d r / d a=V_{a} C_{w} /\left(V_{w} C_{r}-V_{r} C_{w}\right)>0 .
\end{aligned}
$$

These equations imply that in equilibrium, a city with a higher level of amenity has a lower wage rate and a higher land rent. It is an intuitive result. Because workers enjoy amenity, they are willing to accept a lower wage and pay a higher rent in a city with higher amenity. At the same time, firms’ production is not affected by amenity. In a city with higher amenity, a firm can still break even: Although it has to pay a higher rent, it offers a lower wage to workers, so its unit cost remains the same.

\footnotetext{
${ }^{4}$ Many researchers and organizations use this simple housing affordability measure. For example, the World Bank uses this measure as a major indicator of urban development (see http://www.worldbank.org/html/opr/pmi/urban/urban006.html). The central bank of New Zealand also uses this measure in its annual International Housing Affordability Survey (see http://www.demographia.com/dhi.pdf).
} 
Further assume that a worker's demand for land is inelastic, so that an increase in land rent will never lower the worker's expenditure on land. That is, $d(r s) / d r>0$. Together with equations (5) and (6), this assumption implies $d h / d a>0$, meaning that housing is less affordable in a city with a higher level of amenity.

This modeling framework just laid out allows us to examine how unaffordable housing affects local employment growth. Starting with an equilibrium, consider a change in the total number of workers in the national economy. One may imagine that a cohort of college graduates just entered the labor force, or that a group of immigrants just arrived. We ask the following question: Under what conditions will a city with lessaffordable housing experience slower employment growth? Because the composite good is sold on the international market, the influx of workers to a city does not affect the price of $x$. However, in principle, a change in the number of workers $(N)$ in a city would affect $r$ and $w$, and thus a worker's utility in this city.

Differentiating equations (2) and (3) with respect to $N$ and substituting for $d w / d N$ yield:

$$
\left(V_{r}-V_{w} C_{r} / C_{w}\right)(d r / d N) \Delta N=\Delta u .
$$

Equation (7) shows that a change in $N$ affects $r$, which in turn causes a change in a worker's utility through two channels. First, a change in $r$ directly affects a worker's utility (by $V_{r}$ ). Second, the change in $r$ also causes firms to adjust the wage rate so their unit cost remains the same, which in turn affects utility (by $-V_{w} C_{r} / C_{w}$ ).

To illustrate the idea in the simplest way, assume that $\left(V_{r}-V_{w} C_{r} / C_{w}\right)$ is constant across cities. $^{5}$ Note that under both the original equilibrium and the new equilibrium-before and after an influx of workers into the economy-indirect utility has to be the same everywhere. Therefore, $\Delta u$ will be the same in all cities. However, $d r / d N$ may vary from one city to another, which implies that $\Delta N$ will be different in different cities. In particular, a city with a higher $d r / d N$ will have a lower $\Delta N$.

In each city, equilibrium land rent is determined by land supply and demand in the city. Land supply refers to the quantity of land available for industrial or residential

\footnotetext{
${ }^{5}$ One could derive this assumption by imposing conditions on the indirect utility function and the cost function. For example, we may assume the following: (1) in the indirect utility function $V$, $a$ is additively separable from $r$ and $w$; (2) $V$ is linear in $r$ and $w$; and (3) $C$ is linear in $r$ and $w$. Together these assumptions imply that $\left(V_{r}-V_{w} C_{r} / C_{w}\right)$ is a constant everywhere.
} 
uses as a function of land rent. Land demand refers to the quantity of land demanded by workers and firms as a function of land rent, which is ultimately determined by the number of workers who reside in the city and the amenity level in the city.

Assume that the land supply function in each city has the following property: land is perfectly elastically supplied initially. As long as city residents and firms are willing to pay the opportunity cost of land in the agricultural sector, they can use more land and expand the city. However, this process cannot go on forever. After the city boundary reaches a certain limit, reflecting local land-use regulations or geographical constraints, land (for urban uses) can be supplied only at an ever-higher cost (Saks, 2008; Saiz, 2010).

More specifically, it is assumed that city $i$ has an (inverse) land supply function, as follows:

$$
r= \begin{cases}r_{a} & \text { if } q \leq \bar{q}_{i} \\ r_{a}+\left(q-\bar{q}_{i}\right)^{\rho} & \text { if } q>\bar{q}_{i}\end{cases}
$$

where $r$ is land rent in the city, and $q$ is the quantity of land available for residential and industrial uses in the city; $r_{a}$ is the cost of land in the agricultural sector, which, for simplicity, is assumed to be the same everywhere; and $\bar{q}_{i}$ is the maximum amount of land that can be supplied to the city at the opportunity cost in agriculture. Note that $\bar{q}_{i}$ varies from one city to another due to local regulations and geographic conditions. Further assume that $\rho>1$, so that $d r / d q$ increases with $q$ when $q$ is higher than $\bar{q}_{i}$.

It is straightforward to show that in the system of cities described above, employment growth is slower in cities with less affordable housing. Consider a simple heuristic example depicted in Figure 1: an economy with only two cities. Both cities have the same land supply curve, i.e., $S_{1}=S_{2}$. City 1 has a higher amenity level than city 2. Suppose the initial equilibrium is attained when $N_{1}$ workers live in city 1 and $N_{2}$ workers live in city 2, and thus their land demand curves are labeled as $D\left(N_{1}\right)$ and $D\left(N_{2}\right)$. Note that equilibrium land rent in city 1 has to be higher, because city 1 has a higher level of amenity. Also, because city 1 has a higher level of amenity, equilibrium wage rate is lower and therefore housing is less affordable in city 1.

Imagine a small number of workers, $\Delta N$, are now added to the economy. In equilibrium, these new workers will be absorbed by city 2, because the in-migration does 
not influence equilibrium land rent in city 2. More generally, when there are many cities, one would expect that the increase in the number of workers will be smaller in a city where the equilibrium land rent is already on the inelastic portion of the land supply curve.

In other words, in a city with unaffordable housing, employment growth is smaller because equilibrium land rent is very high and land supply is more inelastic. ${ }^{6}$ An inelastic land supply implies that even a small increase in demand for land as a result of employment growth pushes the city's land rent much higher and drives workers to other cities with lower rents. Therefore the city can accommodate only moderate employment growth.

In summary, the model presented above has two implications:

Housing is less affordable in cities with higher amenities. This is because higher amenities lead to lower wages and higher housing prices, which together imply less affordable housing. Higher housing prices in high-amenity cities are mainly driven by higher land rents.

Cities with less-affordable housing experience slower employment growth. Less affordable housing reflects higher equilibrium land rent, and higher land rent indicates inelastic land supply that can be sustained only by more stringent regulatory and/or geographic constraints on the supply of urban land. Thus unaffordable housing is essentially an indicator of binding constraints on land supply. In cities with unaffordable housing, these constraints restrict local employment growth.

\section{Empirical Strategy}

This section discusses the problems associated with estimating the effect of unaffordable housing on employment growth. The estimation equation is the following:

$$
y_{i, t}=\alpha+\beta h_{i, t-1}+\lambda X_{i, t-1}+\tau_{t}+\varepsilon_{i, t},
$$

where the dependent variable $y_{i, t}$ is employment growth in city $i$ and period $t ; h_{i, t-1}$ is the key independent variable measuring housing affordability in city $i$ and period $t-1 ; X_{i, t-1}$

\footnotetext{
${ }^{6}$ One key assumption of this model is that higher amenities lead to both higher land rents and lower elasticities of land supply across cities, and therefore one would expect that higher housing prices are generally associated with less elastic supplies of housing. There is indeed some evidence consistent with its implication. Saiz (2010) shows that in cities where housing prices are high or grow faster, housing supply tends to have lower elasticities (see Figure II on p. 1285).
} 
represents a vector of control variables; $\tau_{t}$ is a year fixed effect; and $\varepsilon_{i, t}$ is the error term of the regression.

It is worth noting here that the theoretical model follows the standard practice since Roback (1982) to assume that all city residents are workers. Of course, in reality city population and total employment are two different concepts. The empirical specification in equation (8) uses employment growth rate as the left-hand-side variable. However, one might suspect that for various reasons cities of different population sizes may experience different rates of employment growth. Therefore, we will include city population size in the equation as one of the control variables.

A simple OLS regression of equation (8) will likely produce a biased estimate of $\beta$. In the theoretical model, equilibrium is assumed to occur instantaneously after any shocks hit the system of cities - the adjustment process is ignored. In empirical work one must treat this assumption with caution, because the adjustment to a new equilibrium takes time, and data collected in out-of-equilibrium situations are likely to bias the coefficients in a simple OLS regression.

There are two types of potential biases. First, there may be some simultaneity bias. The goal of empirical analysis is to investigate how unaffordable housing affects employment growth. However, a simple OLS regression may also pick up a reverse causal effect. For example, rapid job growth in a city, resulting from exogenous shocks, can raise the land rent and thus housing price in the city in the short run (if the city has already reached the inelastic proportion of its land supply curve). Over time, workers and businesses will migrate to other cities to take advantage of the lower rents in those places, pushing land rent and housing price back toward their original equilibrium levels. ${ }^{7}$ If data are collected during this adjustment period, a simple OLS regression may show a positive relationship between unaffordable housing and employment growth, even if unaffordable housing leads to slower employment growth in equilibrium.

The second matter of concern in estimating equation (8) is the problem of omitted variables. A simple OLS regression might fail to take into account some relevant but unobserved factors in some cities, and thus not properly control for their effects. For

\footnotetext{
${ }^{7}$ This kind of transitional dynamics in out-of-equilibrium situations has been studied in related work. See, for example, Sasser (2010) and Zabel (2012), both of which investigate how local economic (and especially housing market) conditions affect the flow of workers across U.S. states or cities.
} 
example, some cities have introduced zoning laws or other land-use regulations that would affect land supply as well as employment growth. Consider a regulatory restriction on land use that pushes land rent, and thus housing price, higher in the short run. Again, over time, workers and businesses will migrate out, so the prices will move back toward their original equilibrium levels. During this adjustment period, both housing affordability and employment will change, although neither one is causing the other to change. Again, data on housing affordability and employment growth may be collected in these out-of-equilibrium situations. If shocks to land supply are not observable or measurable, they will contaminate the estimated effect of unaffordable housing on employment growth that we intend to measure.

A few empirical strategies are employed to tackle the problems with simple OLS regressions. First, empirical analysis is conducted at the city level within a single state, California. This helps avoid the potential bias caused by unobserved heterogeneities at the state or higher levels that we expect to confound empirical studies based on nationwide data.

Second, predetermined affordability is used to predict employment growth in all empirical specifications. The idea is that if growth is not anticipated, it will not affect predetermined affordability measures. Thus the use of independent variables measured at the end of the last period should help mitigate the simultaneity biases.

Third, some specifications will include city fixed effects in the main equation, using within-city variations over time to identify the effect of unaffordable housing on local employment growth. This approach also helps mitigate the potential biases from unobserved heterogeneities across cities.

The fourth strategy is to use the instrumental variables (IV) approach to correct for both the simultaneity and omitted-variables biases in simple OLS regressions. To identify the effect of housing affordability on employment growth in a city, one needs a variable (or a set of variables) that affects local housing affordability but does not directly influence local employment growth. The theoretical model predicts that housing affordability is a function of the amenity level in a city. Thus local amenity measures are natural candidates for instrumental variables used to isolate the effect of housing affordability on employment growth. 
Specifically, we will use weather variables (average July maximum temperature and average January minimum temperature) interacted with state-level energy cost (electricity price) to instrument for housing affordability. The primary reason for using the interaction terms instead of weather variables alone is that energy prices may affect climate (dis)amenities. For example, a hot summer may not be that unbearable if air conditioning is cheap. Therefore, an interaction between extreme temperature and electricity price gives a more accurate measure of the amenity that really matters.

These amenity variables qualify as valid instruments if (1) they are strongly correlated with housing affordability and (2) they can be excluded from the main equation. Condition (1) is implied by the theoretical model, and, as will become evident below, is born out in the data. Condition (2) is a strong assumption we are making to attain model identification. One might worry about the exclusion condition because nice weather tends to attract residents to a city, which is assumed in our model here and documented in earlier studies (e.g., Graves, 1980; Poelhekke, 2006; Rappaport, 2007). That is, equilibrium city population is generally related to climate amenities in the city. However, such amenities do not necessarily affect employment growth rate directly, especially if one believes that climate-induced population migration across cities had reached equilibrium before the study period. Nonetheless, to be cautious, control variables are added in the regressions, including log city population, the proportion of adult population with a bachelor's degree, and time dummies. ${ }^{8}$ After controlling for a city's equilibrium population level and its equilibrium employment of skilled labor, it seems reasonable to assume that employment growth rate is not directly affected by weather.

With instrumental variables, the effect of housing affordability on local employment growth is estimated using the two-stage least squares (2SLS) method,

\footnotetext{
${ }^{8}$ Limited data availability and poor data quality dictate that we cannot include many controls in our baseline regressions. The two variables included here, population size and share of adult population with a bachelor's degree, are both crucial for model identification. Early empirical research has found a correlation between city population and temperature (e.g., Glaeser and Shapiro, 2003; Glaeser and Gyourko, 2005; Glaeser and Gottlieb, 2009). Existing literature has also documented that cities with more human capital grow faster (e.g., Black and Henderson, 1999; Glaeser and Shapiro, 2003) and that skilled workers may have stronger preferences for high amenities and a robust labor market (e.g., Glaeser and Gyourko, 2005; Rappaport, 2007; Chen and Rosenthal, 2008). Thus, if population size and human capital level are not controlled, it may bias our IV estimates that exploit variations from climate amenities.
} 
treating housing affordability as an endogenous variable in equation (8). The first stage equation is given by

$$
h_{i, t-1}=\gamma+\theta A_{i, t-1}+\delta X_{i, t-1}+\mu_{t-1}+\eta_{i, t-1},
$$

where, as before, the subscripts $i$ and $t$ index cities and years; $X_{i, t-1}$ is a vector of city characteristics as controls; $\mu_{t-1}$ represents a year fixed effect; and $A_{i, t-1}$ is the set of instruments. The predicted housing affordability $(\hat{h})$ from this first-stage regression is used to estimate the employment growth equation in the second stage.

Although the instrumental variables method is used primarily to deal with simultaneity and omitted-variables problems, it can also be employed to correct for biases stemming from classical measurement errors in independent variables. In the present analysis, if one suspects that the housing affordability variable is not precisely measured, the instrumental variables will also help correct biases introduced by such measurement errors.

Ideally, one would estimate fixed-effects models using instrumental variables, which presumably will produce the most convincing results. Unfortunately, the climate amenity variables used as instruments do not vary a lot within a small area, especially over a short period of time. Consequently, these instruments are not useful in fixedeffects models. Therefore, the empirical analysis presented below tries the IV approach and the fixed-effects approach separately.

\section{Data and Variables}

This section describes the data sources and the variables constructed for empirical analysis.

Our empirical analysis is conducted at the level of California municipalities. The main advantage of focusing on one state is that there will be less unaccounted-for heterogeneities created by state policies, because all the jurisdictions within a state are subject to the same state-level regulations. However, a state may be too small to have wide regional variations. For this reason, we have chosen a large state where both housing prices and climate amenities vary drastically across regions. Regression analysis at the municipality level instead of the county or metropolitan-area level ensures a reasonably large number of observations. Our analysis focuses on employment growth 
over two-year periods from 1993 to 2004. The choice of these time intervals is largely dictated by data availability.

\section{Dependent Variables}

Employment growth: For California cities, two-year employment growth is calculated using data from the state's Employment Development Department. This database contains average yearly employment at the city level, collected by the department's Labor Market Information Division in cooperation with the U.S. Department of Labor and the Bureau of Labor Statistics. California's official city-level employment statistics are based on these data.

\section{Independent and Control Variables}

Housing affordability: This variable is calculated by dividing city-level median housing price by county-level median household income. ${ }^{9}$ Data on median housing sales prices are downloaded from the Business and Economic Statistic Division of RAND California. ${ }^{10}$ RAND originally acquired these data from the California Association of Realtors. The price reflects both sales of new homes and resales. RAND has price data from 1991 to 2002, all measured in nominal dollars.

County-level median household income data come from the Small Area Income and Poverty Estimates (SAIPE) program of the U.S. Census Bureau. The program provides estimates of key income and poverty statistics for small geographic areas in non-census years. Prior to 1998, the bureau produced county-level income data every two years, in odd-numbered years only, so data are not available for 1994 and 1996. The missing data for these two years are imputed by taking the average of the preceding and the following year. Thus it is possible to calculate the affordability ratio for each city in each year.

Fraction of adult population with a bachelor's degree: Data on educational attainment come from the SF-3 and STF-3 files of the 2000 and 1990 Census, respectively. These data give the share of the adult population 25 years and older with a

\footnotetext{
${ }^{9}$ We use county- instead of city-level median household income to measure affordability for two reasons. First, for the smaller municipalities in the sample, many people living outside of the city boundary are also potential local house buyers, and calculating the affordability index using county-level income takes into account the purchasing power of such potential buyers. Second, reliable information on city-level median household income is more difficult to come by and subject to serious measurement errors.

${ }^{10}$ See http://ca.rand.org/stats/economics/houseprice.html.
} 
bachelor's degree in each city for the two census years. The data for other years from 1992 to 2004 are imputed, assuming a linear trend.

City population: Population data for California cities are downloaded from the website of the state Department of Finance. They estimate the total population of each city each year based on the 1990 and 2000 Census data. ${ }^{11}$

\section{Instrumental Variables}

July and January temperature: These weather variables are obtained from the National Climatic Data Center's monthly surface data files (DS320). ${ }^{12}$ The center's database includes monthly surface data from 18,000 stations, sited in major cities as well as some small towns. For the present analysis, data on the July maximum temperature and January minimum temperature are extracted for all available, active California weather stations. Both temperature variables are calculated by averaging the daily maximum or minimum temperature over the month's 31 days. City names (contained in whether station names) allow us to match the weather variables with other city-level data. In a few cases, when a single city has multiple weather stations, the simple average of the data recorded at those stations is used.

California state level electricity price: Data on annual electricity prices for California are obtained from the Energy Information Administration. ${ }^{13}$

\section{Empirical Results}

This section reports empirical findings.

\section{Descriptive Statistics}

There are 478 incorporated cities and towns in California, but the NCDC city list for California is much shorter, because many smaller cities have no weather stations. After matching all the variables from different sources, the study sample covers 115 cities in the state for the period 1993-2004, including all the large cities. The housing price variable and the weather variables may be missing for certain years for some cities, and therefore this sample is not a balanced panel. Table 1 presents descriptive statistics for the dependent, independent/control, and instrumental variables.

\footnotetext{
11 These city-level population estimates, and the methodology used for the estimates, are available at http://www.dof.ca.gov/HTML/DEMOGRAP/ReportsPapers/ReportsPapers.asp.

${ }^{12}$ See http://cdo.ncdc.noaa.gov/CDO/cdo.

${ }^{13}$ See http://www.eia.doe.gov/cneaf/electricity/st_profiles/sept08ca.xls.
} 
The average California city in the sample has 140,295 residents, with an employment level of 64,014. Average employment growth is 2.0 percent over one year and 3.9 percent over two years. The key independent variable- the housing affordability ratio-averages 4.5. It varies substantially, ranging from a minimum of 0.78 to a maximum of 16.42. Table 2, which lists the housing affordability ratio for a selected group of cities in California, illustrates this variation. For example, the mean ratio in the inland city of Fresno is 2.97, while it is as high as 11.46 in the coastal city of Santa Monica.

The weather variables, shown in Table 1, also reveal a great deal of variation across cities. The July maximum temperature ranges from a minimum of 62.2 degrees to a maximum of 111.8 degrees, and the January minimum temperature ranges from a minimum of 9.9 degrees to a maximum of 52.4 degrees.

Figure 2 shows a scatterplot of two-year employment growth over affordability ratio. The employment growth rate indeed appears to be negatively correlated with the affordability ratio, which is clearly shown by the fitted straight line. That is, municipalities with a higher affordability ratio (and thus less affordable housing) tend to have slower employment growth. This is only an unconditional correlation, but it is indicative that unaffordable housing may have a negative effect on employment growth.

Figure 3 graphs the relationship between the housing affordability ratio and the instrumental variables. Panel (a) shows that the interaction between July maximum temperature and electricity price is negatively correlated with the housing affordability ratio. Housing is more affordable (with a higher affordability ratio) in cities where it is hot in July. The relationship appears to be linear and very strong, suggesting that this instrumental variable will easily meet the relevance condition. Panel (b) shows a positive relationship between the affordability ratio and the interaction between January minimum temperature and electricity price, indicating that areas with a warm winter tend to have less affordable housing.

\section{OLS and IV estimates}

Table 3 presents OLS and IV regression results for California cities. To focus on the independent variable of interest, the coefficients of control variables are not included 
in the table. Standard errors are clustered by county, allowing for both spatial and serial correlations among all observations within a county. ${ }^{14}$

The OLS results are in the upper panel of Table 3. In the left column is the specification without city fixed effects. In this regression, housing affordability has a negative coefficient, but its magnitude is small (-0.3 percent), and it is not statistically significant. That is, a simple comparison across cities does not reveal slower employment growth in less-affordable cities. The right column in the upper panel shows the estimate from the specification with city fixed effects. Here the coefficient is still negative but much larger (-2.5 percent), and it is statistically significant at the 1 percent level. Therefore, when focusing on within-city changes over time, we do find that slower employment growth tends to follow years with less-affordable housing.

The two regressions in the upper panel of Table (3) indicate that the OLS estimate without controlling city fixed effects is biased toward zero. To understand this bias, let us consider two cities: San Jose and Fresno. Suppose indeed that within both cities slower employment growth follows periods with less affordable housing. Thus the fixedeffects OLS regression will reveal the negative effect of unaffordable housing on employment growth. Additionally, suppose that in San Jose, innovation creates new jobs and thus increases employment as well as housing prices. As a result, San Jose has both less affordable housing and faster employment growth than Fresno. That is, although within-city variations imply a negative effect of unaffordable housing on employment growth, between-city variations imply a positive effect. An OLS regression without controlling for city dummies mixes up these two effects and thus biases the estimate toward zero. An IV regression excluding city dummies also uses both within- and between-city variations. However, since the variations are exogenous and come from climate amenities, the IV regression helps correct the omitted variables biases generated from the between-city variations.

The lower panel of Table 3 shows the IV estimates, without controlling for city fixed effects. Different variables are used to instrument for the housing affordability ratio

\footnotetext{
${ }^{14}$ OLS regressions typically assume independently and identically distributed (iid) error terms. When estimation uses clustered data (i.e., the observations are grouped), the iid assumption may be violated. In these situations, a standard (and more conservative) practice is to make statistical inferences using clustered standard errors that allow for arbitrary patterns of correlation within groups. See Wooldridge (2003) for a discussion of cluster methods.
} 
in the first-stage regression, including (1) July maximum temperature interacted with electricity price, (2) January minimum temperature interacted with electricity price, and (3) both interaction variables. Correspondingly, three sets of IV estimates are reported.

All the IV estimates show a statistically significant negative relationship between the housing affordability ratio and city-level employment growth. In each case, the coefficient is less negative $(-1.2,-1.9$ or -1.5 versus -2.5 percent) than the OLS estimate with city fixed effects. To understand this discrepancy, it is important to recognize that the IV regression estimates the coefficient mainly based on exogenous cross-sectional variation in housing affordability because weather variables (even interacted with electricity price) contain little over-time variation within a city. In contrast, the fixedeffect OLS estimate entirely relies on within-city variation over time. Given that the within-city variation is not necessarily exogenous, one might find the IV estimates more convincing than the fixed-effects OLS estimate.

Consider our preferred IV specification, the third column that uses both interaction variables as instruments. The coefficient of the affordability ration is -0.015 . This implies that if a city’s housing affordability ratio is higher by one unit (or about half a standard deviation), its employment growth rate over two years is expected to be lower by one and half percentage points. This is a rather large effect, given that total employment in the average city grows by only 3.9 percent over two years (as shown in Table 1).

For all IV regressions, Table 3 also presents standard errors of the key coefficient based on alternative clustering methods. Standard errors clustered on county-years, allowing for spatial correlations within a county in a single year, are shown in square brackets under the estimated coefficients. Standard errors clustered by city, allowing for serial correlations within the city over different years, are shown in curly brackets. In general, clustering on county-year leads to smaller standard errors than in the baseline regressions, and clustering on city leads to larger standard errors. However, in both cases the standard errors change only slightly from the baseline results, and the coefficient of the housing affordability ratio remains statistically significant under all specifications. 
Table 3 also presents some results regarding the validity of the instrumental variables and regarding the presence of endogeneity biases in the OLS estimates. All these results are based on standard errors clustered by county.

Valid instruments must be correlated with the endogenous variable, and orthogonal to the error term. An F test for the joint significance of the instrumental variables in the first-stage regressions is performed to check the correlation between the instruments and the endogenous variable. This statistic ranges from 15.7 to 38.3 across different IV specifications, and is consistently greater than 10 , suggesting that the instruments used in these regressions have good explanatory power. ${ }^{15}$

In the third column, two interaction variables are used as instruments, although there is only one endogenous variable. This allows the use of an overidentifying test to check the validity of the instruments. Specifically, we conduct Hansen's J test for the null hypothesis that both instruments are proper instruments. The p-value reported in Table 3, 0.319, suggests that the null hypothesis cannot be rejected.

Although the discussion of estimation problems clearly suggested the potential endogeneity between employment growth and housing affordability, it is still instructive to empirically test for the presence of endogeneity here. Table 3 shows the p-values of the statistics from the endogeneity tests. For all three specifications, these tests reject the null hypothesis (at the 10 percent level) that the OLS coefficient is unbiased. That is, it is likely that endogeneity is present when measuring the effect of unaffordable housing on employment growth and can potentially lead to seriously biased estimates in OLS regressions. Therefore, an IV estimate is preferred in this case.

The 2SLS regressions in Table 3 do not include county or city fixed effects. Presumably, such fixed-effects IV regressions would be the preferred specifications, because they would be the most conservative approach to dealing with unobserved heterogeneities among the cities. However, as noted, year-to-year variations in both housing affordability and the weather variables would be small within any small geographic region over a short period. Therefore the correlation between these two

\footnotetext{
${ }^{15}$ A common problem in IV estimations is that of "weak instruments," even when the first stage results are statistically significant and the sample is fairly large. The rule of thumb for a single endogenous variable is that there is unlikely to be a weak-instrument problem if the first-stage F-statistic is greater than 10 . An Fstatistic below 10 is a reason for concern (Staiger and Stock, 1997).
} 
variables would be too weak to identify the effects of unaffordable housing in fixedeffects models.

Because the affordability ratio variable and city-level weather variables are observed in every year, it is certainly possible to run the regressions with county or city fixed effects. Indeed, with county or city fixed effects, the first-stage F-statistics are small across all the specifications, confirming that the year-to-year correlation between weather variables and housing affordability within a county or a city is not strong enough to help identify the effects of unaffordable housing. The estimated coefficients under these fixed effects models blow up in some cases, and can never be precisely estimated. Since these exercises are not informative, we consider the baseline IV regressions (without controlling for county or city fixed effects) as our best-attainable results.

Table 4 reports results from some robustness checks. The first alternative specification adds another control variable: a dummy for coastal counties. The negative effect observed in the baseline IV regressions might result from the fact that housing is generally less affordable in coastal cities (refer to Table 2). In other words, the estimated coefficients in Table 3 might be picking up only this "coast effect." By introducing the coastal dummy, this alternative specification identifies the effects of unaffordable housing using only the variations within the coastal or inland areas.

Panel A of Table 4 shows the results from the regressions with the coastal dummy. As with the baseline regressions, standard errors are clustered by county. The IV coefficients are all negative. They are estimated with less precision but two of the three are still statistically significant. This suggests that although the variations between coastal and inland cities play a role in identifying the effect of unaffordable housing on employment growth, they alone are not driving the results. Our preferred specification, which uses both interaction variables as instruments, gives an estimated coefficient of 0.016, almost identical to the estimate without controlling for the coastal dummy.

Panel B of Table 4 reports results from specifications using more city-level controls. In all the specifications presented above, log city population and the percentage of adult population with a bachelor's degree in the city are included as controls. Here we 
check whether our baseline results are sensitive to including more city level controls. ${ }^{16}$ High frequency data on city characteristics are not easily available. We hand-collect information from the 1994, 2000, and 2007 editions of the County and City Data Book published by the U.S. Census Bureau, and impute the data for the years in between by linear interpolation. The extra city level control variables are related to local public finance, economic structure, and living environment, including (1) per capita government general expenditure; (2) share of government expenditure spent on road, fire protection, and police; (3) retail and wholesale employment as a share of total employment; (4) manufacturing employment as a share of total employment; and (5) violent crime rate. The choice of these variables is dictated entirely by data availability. Since these variables are missing for some cities, we end up with a smaller sample size. As it turns out, adding these extra control variables has no significant effect on our qualitative results. In fact, the estimated coefficients are very similar to those in the baseline regressions. $^{17}$

Overall, results from these alternative specifications also consistently point to a negative effect of unaffordable housing on local employment growth in California. Our preferred specification, which uses both amenity variables as instruments, suggests that a one-unit increase in the housing-price-to-income ratio reduces city-level employment growth by 1.6 percentage points over two years, almost identical to the baseline estimate. $^{18}$

\footnotetext{
${ }^{16}$ Despite the work of Saks (2008) and Saiz (2010) that emphasizes the role of regulatory and geographic constraints on housing supply in local economic development, such constraints are not considered as potential additional control variables. In the theoretical model, high local amenities imply high equilibrium housing prices. Such high housing prices (and thus low affordability) can only be sustained by stringent regulatory and geographic constraints on land and housing supply. Therefore, unaffordability is essentially an indicator of more constraints on land and housing supply, and it is these constraints that impede local employment growth. The empirical analysis in this paper is meant to investigate how unaffordable housing affects employment growth through (instead of conditional on) constraints on land and housing supply. Thus such constraints are not controlled here.

${ }^{17}$ We have also tried including both the coastal dummy and the extra city level controls in the regression. The coefficients are also all negative, although like in panel A of Table 4 only two of them are statistically significant.

${ }^{18}$ Although not presented here for reasons of space, we also conducted parallel empirical analysis using census data on U.S. metropolitan areas and U.S. counties over ten-year periods (Chakrabarti and Zhang 2010). The results are remarkably consistent with the findings reported here.
} 


\section{Conclusion and Discussion}

Housing prices vary substantially across different areas of the United States. Persistently higher housing prices in certain regions always cause concerns in those areas, because unaffordable housing is expected to have negative effects on the local economy. Yet there is little empirical evidence on such perceived effects. This paper attempts to study whether unaffordable housing impedes local employment growth.

A simple theoretical model is proposed to explain why housing affordability could affect regional employment growth. In the model, the variation of housing affordability is driven by heterogeneities in location-specific amenities. Cities with lessaffordable housing tend to experience slower employment growth, because equilibrium land rents are so high that the supply of land must have reached some constraints. These land supply constraints are the ultimate restrictions on local employment growth. Note that many land-supply constraints are actually man-made and created by land-use regulations. This model implies that when high housing prices are sustained by tight land-use regulations, they lead to slower employment growth. This is consistent with the findings of the existing literature that focuses on land-use regulations, such as Glaeser and Gyourko (2003), Quigley and Raphael (2005), and Sacks (2008).

Potential endogeneity biases create a major problem in empirical studies of the effect of unaffordable housing. While housing prices may affect local employment growth, job growth could also make the local economy more prosperous, leading to an increase in housing prices. In addition, omitted variables also cause complications in empirical analysis. Many unobserved factors could affect housing affordability and employment growth simultaneously, resulting in spurious correlations between the two variables. All of these can bias the estimates obtained through simple OLS regressions. This study has employed various empirical strategies to correct for the potential simultaneity and omitted-variables biases. Most importantly, identification relies on the instrumental variables approach. As suggested by the theoretical model, the empirical study uses measures of climate amenities, such as July maximum temperature and January minimum temperature (interacted with electricity price), to instrument for the housing affordability measure. 
The IV regression results show significant negative effects of unaffordable housing on local employment growth. For California cities, other things being equal, a one-unit lower housing affordability ratio is associated with a two-year employment growth rate that is about one and half percentage points higher.

One limitation of this study is that the instrumental variables do not contain enough over-time variations to help identify the within-city effect of unaffordable housing. The OLS estimate controlling for city dummies suggests that the within-city effect is also negative. However, this estimate is not based on exogenous variations and may be subject to some endogeneity bias. Therefore one must interpret this result on within-city effect with caution and further research is warranted along this line.

This study is primarily motivated by local policymakers' concerns about the possible negative effects of unaffordable housing. Because the empirical results indeed show a relationship between unaffordable housing and employment growth, one might ask whether these findings have any policy implications.

As mentioned above, our IV estimate is mainly based on cross-sectional variation in climate amenities. The negative IV coefficient thus implies that cities with less affordable housing are likely to experience slower employment growth than other cities. From this perspective, the local policymakers' concerns are well grounded.

A related and perhaps more important question is whether a local policy to provide more affordable housing will help increase employment growth. This is mainly about the within-city effect for which our estimate is not as reliable. Interestingly, even if one trusts the qualitative result from the fixed-effects OLS regression, the negative coefficient does not imply that any policy that makes housing more affordable will have a positive effect on employment growth. This becomes clear if we try to understand policy implication within our theoretical framework. For example, a policy reducing local amenities will lead to more-affordable housing, but it will also make the region less attractive and drive people away. Such a policy will not stimulate employment growth. A policy relaxing constraints on land supply, in contrast, will help make housing more affordable in the short run. All else equal, such a policy will make a region more attractive to both workers and firms, and will lead to faster employment growth during the transition to a new equilibrium. 
Note that because amenity ultimately determines housing affordability, a policy that does not change the level of local amenity will have no effect on affordability in the long run. This also implies that not all policies aimed at unaffordable housing will affect real variables. For example, if policymakers aim to make housing more affordable by subsidizing rents or homeownership, they will only induce residents to bid housing prices higher. Such a policy will eventually lead to even higher housing prices, and is unlikely to have any effect on employment. 


\section{References}

Bartik, Timothy J. (1991), Who Benefits from State and Local Economic Development Policies? Kalamazoo, MI: W.E. Upjohn Institute for Employment Research.

Black, Duncan, and Vernon Henderson (1999), “A Theory of Urban Growth,” Journal of Political Economy 107, 252-284.

Bover, Olympia, John Muellbauer, and Anthony Murphy (1989), "Housing, Wages and UK Labour Markets,” Oxford Bulletin of Economics and Statistics 51, 97-136.

Chakrabarti, Ritashree, and Junfu Zhang (2010), “Unaffordable Housing and Local Employment Growth,” Working Paper 10-3, New England Public Policy Center at the Federal Reserve Bank of Boston.

Chen, Yong, and Stuart S. Rosenthal (2008), “Local Amenities and Life-Cycle Migration: Do People Move for Jobs or Fun?” Journal of Urban Economics 64, 519-537.

Glaeser, Edward L. (2006), “The Economic Impact of Restricting Housing Supply,” Cambridge, MA: Rappaport Institute for Greater Boston, Harvard Kennedy School.

Glaeser Edward L., and Joshua D. Gottlieb (2009), “The Wealth of Cities: Agglomeration Economies and Spatial Equilibrium in the United States," Journal of Economic Literature 47, 983-1028.

Glaeser, Edward L., and Joseph Gyourko (2003), “The Impact of Zoning on Housing Affordability,” Economic Policy Review 9(2), pp. 2139. New York, NY: Federal Reserve Bank of New York.

Glaeser, Edward L., and Joseph Gyourko (2005), “Urban Decline and Durable Housing,” Journal of Political Economy 113, 345-375.

Glaeser, Edward L., and Joseph Gyourko (2007), "Housing Dynamics,” Discussion Paper no. 2137. Cambridge, MA: Harvard Institute of Economic Research.

Glaeser, Edward L., Joseph Gyourko, and Raven Saks (2005a), “Why Have Housing Prices Gone Up?” American Economic Review Papers and Proceeding 95, 329-333.

Glaeser, Edward L., Joseph Gyourko, and Raven Saks (2005b), "Why Is Manhattan So Expensive? Regulation and the Rise in Housing Prices," Journal of Law and Economics 48, 331-369.

Glaeser, Edward L., Joseph Gyourko, and Raven Saks (2006), “Urban Growth and Housing Supply,” Journal of Economic Geography 6, pp. 71-89.

Glaeser, Edward L., and Jesse M. Shapiro (2003), "Urban Growth in the 1990s: Is City Living Back?” Journal of Regional Science 43, 139-165.

Glaeser, Edward L., and Bryce A. Ward (2009), "The Causes and Consequences of Land Use Regulation: Evidence from Greater Boston,” Journal of Urban Economics 65, 265278.

Graves, Philip E. (1980), “Migration and Climate,” Journal of Regional Science 20, 227237. 
Gyourko, Joseph, Christopher Mayer, and Todd Sinai (2013), "Superstar Cities," American Economic Journal: Economic Policy 5, 167-99..

Gyourko, Joseph, and Albert Saiz (2006), "Construction Costs and the Supply of Housing Structure,” Journal of Regional Science 46, 661-680.

Hwang, Min, and John M. Quigley (2006), "Economic Fundamentals in Local Housing Markets: Evidence from U.S. Metropolitan Regions,” Journal of Regional Science 46, 425-453.

Ihlanfeldt, Keith (2007), "The Effect of Land Use Regulation on Housing and Land Prices,” Journal of Urban Economics 61, 420-435.

Johnes, Geraint, and Thomas Hyclak (1994), "House Prices, Migration, and Regional Labor Markets,” Journal of Housing Economics 3, 312-329.

Johnes, Geraint, and Thomas Hyclak (1999), "House Prices and Regional Labor Markets," Annals of Regional Science 33, 33-49.

Poelhekke, Steven. 2006. "Do Amenities and Diversity Encourage City Growth? A Link through Skilled Labor.” Working paper no. 2006/10. Florence, Italy: European University Institute.

Quigley, John M., and Steven Raphael (2005), "Regulation and the High Cost of Housing in California," American Economic Review Papers and Proceedings 95, 323-329.

Rappaport, Jordan (2007), "Moving to Nice Weather," Regional Science and Urban Economics 37, 375-398.

Roback, Jennifer (1982), “Wages, Rents, and the Quality of Life,” Journal of Political Economy 90, 1257-1278.

Saiz, Albert (2010), “The Geographic Determinants of Housing Supply,” Quarterly Journal of Economics 125, 1253-1296.

Saks, Raven E. (2008), "Job Creation and Housing Construction: Constraints on Employment Growth in Metropolitan Areas," Journal of Urban Economics 64, 178-195.

Sasser, Alicia C. (2010), "Voting with Their feet: Relative Economic Conditions and State Migration Patterns.” Regional Science and Urban Economics 40, 122-135.

Staiger, Douglas, and James H. Stock (1997), "Instrumental Variables Regressions with Weak Instruments,” Econometrica 65, 557-586.

Wooldridge, Jeffrey M. (2003), "Cluster-Sample Methods in Applied Econometrics," American Economic Review Papers and Proceedings 93 (2), 133-138.

Zabel, Jeffrey (2012), "Migration, Housing Market, and Labor Market Responses to Employment Shocks,” Journal of Urban Economics 72, 267-284. 


\section{Box 1: Media Excerpts on Concerns That Unaffordable Housing Will Undercut the Local Economy}

Limits on immigration, rising global competition for skilled workers and California's high housing prices will impede the state's ability to meet its future economic demand, according to the study's author Hans Johnson and Deborah Reed. ...... From 2000 to 2005, California lost more college graduates to other states than it gained, reversing a long trend of attracting them. The researchers said that the state's high housing prices were a prime cause. ...... The outlook could change, the researchers said, if housing prices fall and wages rise, making California more attractive.

Los Angles Times, May 24, 2007

A report being released today predicts robust job growth in Silicon Valley and the Bay Area economy over the next 10 years. But finding workers who are willing to put up with the area's high housing prices will be daunting.

San Jose Mercury News, February 16, 2007

High home prices are limiting the Boston area's ability to regain the jobs lost in the 2001 recession and sustain economic growth, according to two new studies being released today during a conference at Boston's Federal Reserve Bank. ..... Massachusetts employers often cite high housing prices as a major reason they expand operations in other states, where costs and therefore, the wages they pay are lower.

Boston Globe, May 22, 2006

For the first time in more than three decades, the population of San Diego County declined last year, joining other Californian coastal counties that are losing their allure as high housing prices drive home-buyers to more affordable regions.

The San Diego Union-Tribune, March 16, 2006

Over the pat five years, the Bay Area's high housing prices have driven many residents to seriously consider leaving for less-expensive environs, according to a new poll. The numbers seem to illustrate what has long been a regional worry: that astronomical home price could eventually lead to a decline in competitiveness as talented workers move away looking for a better quality of life.

Contra Costa Times, February 27, 2006

Mayor Jerry Sanders pledged yesterday to place affordable housing and land-use issues on an equal footing with solving San Diego's many financial problems. ...... "There's nothing I can promise as a mayor that's going to draw a company here because I can’t give them housing at much cheaper cost than you can in Phoenix,” he said.

The San Diego Union-Tribune, January 11, 2006

Boston, like San Francisco and San Jose, finds its job growth constrained by the high cost of doing business, with skyhigh housing prices front and center......

Boston Herald, December 3, 2005

Moving in and moving on; Washington area is a 'funnel': people come for jobs, leave to find cheaper housing.

Washington Post, November 26, 2005

[W] hen housing costs outstrip wages, families start doubling up in homes intended for only one household or move farther from their jobs to find cheaper housing. They eventually tire of their long commutes and move away. When employers can't supply their labor needs locally, they, too, go elsewhere. Tampa Bay officials know that the local economy will soon feel the effects if they cannot find a way to boost the supply of affordable housing.

St. Petersburg Times, November 25, 2005

Is the sun and surf of San Diego enough to lure choice recruits to local companies? After doing the math, many job candidates are scared off by S.D.’s high housing prices.

The San Diego Union-Tribune, September 5, 2004 


\section{Figure 1: Land Market in Two Cities}

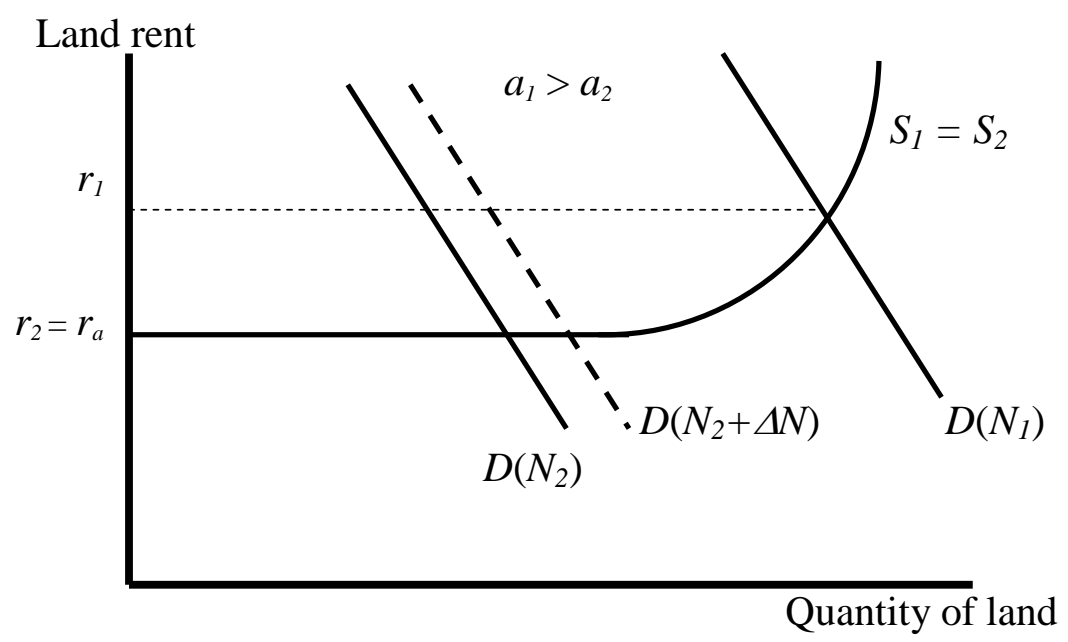

Note: In this example, there are only two cities in the economy. $S_{1}$ and $S_{2}$ are land supply curves in the two cities, which are assumed to be identical. Land is infinitely elastically supplied until the city boundary hits constraints imposed by land-use regulations or geography, beyond which urban land can be supplied only at an ever-higher cost. City 1 has a higher level of amenity: $a_{1}>a_{2}$. Suppose that the initial equilibrium is attained when $N_{1}$ workers live in city 1 and $N_{2}$ workers in city 2 . Note that equilibrium land rent in city 1 is higher $\left(r_{1}>r_{2}\right)$ because of the higher level of amenity in city 1. As a result, housing price is higher and wage is lower in city 1 . Assume that now a small number of new workers, $\Delta N$, just entered the economy. In the new equilibrium, these workers are absorbed by city 2, because this in-migration does not alter the equilibrium land rent in city 2 . Under the new equilibrium, the land demand curve in city 1 is unchanged, and the land demand curve in city 2 has moved to the right (the dash line). That is, employment growth occurs only in the city with more-affordable housing (city 2). 
Figure 2: Housing Affordability and Two-Year Employment Growth in California Cities

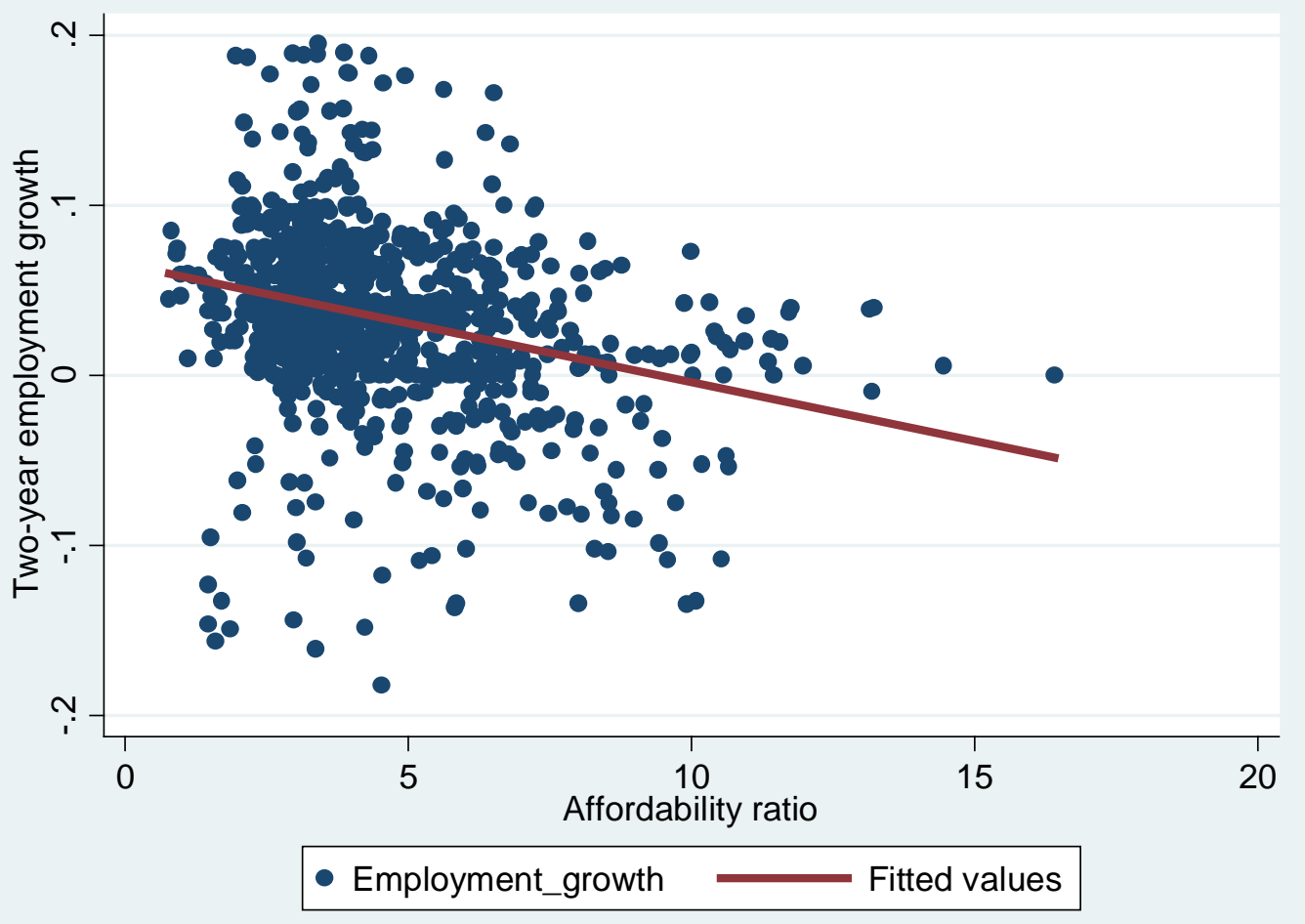

Note: A higher housing-price-to-income "affordability ratio" means that housing is less affordable.

Employment growth is regressed on affordability ratio, and the estimated coefficient is then used to predict the "fitted value" at each affordability ratio. 
Figure 3: Correlation between IVs and Housing Affordability in California Cities

(a) Housing affordability vs. July maximum temperature*electricity price

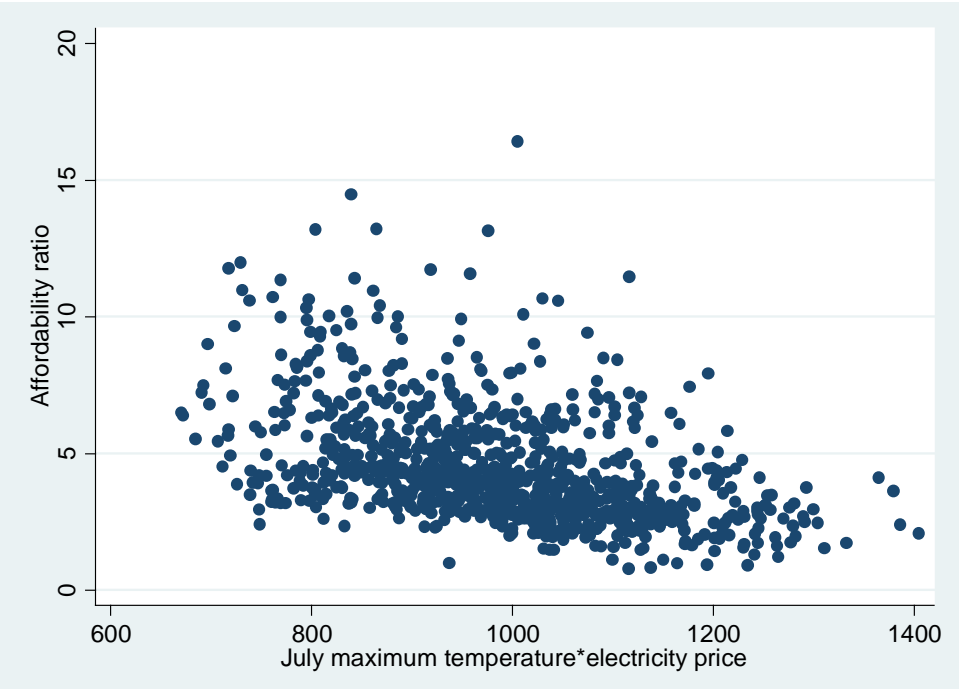

(b) Housing affordability vs. January minimum temperature*electricity price

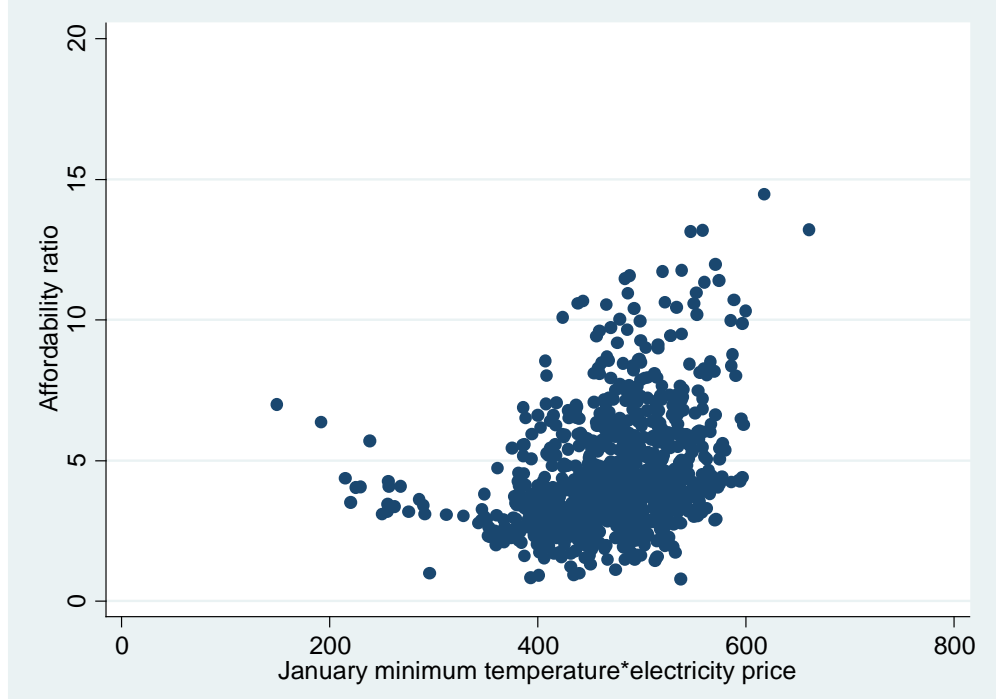

Note: In both panels (a) and (b), a higher housing-price-to-income "affordability ratio" means that housing is less affordable. 
Table 1: Descriptive Statistics for California Cities

\begin{tabular}{|c|c|c|c|c|c|}
\hline \multirow[b]{2}{*}{ Variables } & \multirow[b]{2}{*}{ Variable Description } & \multicolumn{4}{|c|}{ Summary Statistics } \\
\hline & & Mean & $\begin{array}{l}\text { Std. } \\
\text { Dev. }\end{array}$ & Min & Max \\
\hline \multicolumn{6}{|c|}{ Dependent Variables } \\
\hline total_emp & Total city employment in California & 64,014 & 175,159 & 570 & $1,733,300$ \\
\hline lmid_empg1 & $\begin{array}{l}\text { City-level employment growth over a } \\
\text { one-year period in California }\end{array}$ & 0.02 & 0.055 & -0.684 & 0.488 \\
\hline lmid_empg2 & \begin{tabular}{|l|}
$\begin{array}{l}\text { City-level employment growth over a } \\
\text { two-year period in California }\end{array}$ \\
\end{tabular} & 0.039 & 0.078 & -0.662 & 0.498 \\
\hline \multicolumn{6}{|c|}{ Independent/Control Variables } \\
\hline $\begin{array}{l}\text { affordability } \\
\text { ratio }\end{array}$ & $\begin{array}{l}\text { Median home price in the city, divided by } \\
\text { median household income in the county }\end{array}$ & 4.49 & 2.11 & 0.78 & 16.42 \\
\hline $\begin{array}{l}\text { percent_bache } \\
\text {-lor }\end{array}$ & \begin{tabular}{|l|} 
Percentage of population 25 years and \\
older in the city with a bachelor's degree
\end{tabular} & 15.31 & 7.58 & 3.06 & 37.99 \\
\hline tot_pop & City-level annual population & 140,295 & 389,261 & 1374 & 3,822,955 \\
\hline \multicolumn{6}{|c|}{ Instrumental Variables } \\
\hline jul_max & July mean maximum temperature & 86.07 & 10.78 & 62.2 & 111.8 \\
\hline jan_min & January mean minimum temperature & 40.99 & 5.73 & 9.9 & 52.4 \\
\hline elect_price & Annual electricity price in California & 11.41 & 0.60 & 10.6 & 12.64 \\
\hline
\end{tabular}

Note: Employment growth is defined as the difference in log employment. Data on the percentage of the adult population with a bachelor's degree are from the 2000 and 1990 decennial Census. This variable is available only for the two Census years. We impute the figures for other years from 1993 to 2002 by linearly interpolating and extrapolating the Census data. 
Table 2: Summary Statistics on the Housing Affordability Ratio for Selected California Cities, 1993-2004

\begin{tabular}{||l|c|c|c|c||}
\hline \multirow{2}{*}{ City Name } & \multicolumn{4}{|c|}{ Housing-Price-to-Income Ratio } \\
\cline { 2 - 5 } & \multicolumn{1}{|l|}{ Mean } & $\begin{array}{l}\text { Standard } \\
\text { Deviation }\end{array}$ & Minimum & Maximum \\
\hline Anaheim & 3.75 & 0.53 & 3.28 & 4.97 \\
\hline Bakersfield & 2.88 & 0.31 & 2.42 & 3.40 \\
\hline Burbank & 5.86 & 1.04 & 4.99 & 8.49 \\
\hline Fresno & 2.97 & 0.37 & 2.52 & 3.48 \\
\hline Laguna Beach & 9.32 & 2.10 & 7.08 & 13.16 \\
\hline Lodi & 3.74 & 0.44 & 3.32 & 4.69 \\
\hline Long Beach & 4.62 & 0.61 & 4.00 & 6.00 \\
\hline Los Angeles & 4.81 & 0.76 & 4.05 & 6.49 \\
\hline Los Banos & 4.57 & 0.87 & 3.84 & 5.92 \\
\hline Los Gatos & 8.01 & 1.30 & 6.54 & 10.09 \\
\hline Madera & 2.93 & 0.29 & 2.69 & 3.50 \\
\hline Merced & 3.45 & 0.47 & 3.05 & 4.12 \\
\hline Modesto & 3.22 & 0.57 & 2.75 & 4.38 \\
\hline Monterey & 8.26 & 1.22 & 6.90 & 9.97 \\
\hline Newark & 5.27 & 1.14 & 4.11 & 7.33 \\
\hline Oceanside & 4.21 & 0.62 & 3.71 & 5.72 \\
\hline Sacramento & 2.84 & 0.54 & 2.38 & 3.94 \\
\hline San Bernardino & 2.20 & 0.23 & 1.94 & 2.64 \\
\hline San Diego & 4.58 & 0.65 & 4.16 & 6.26 \\
\hline San Francisco & 7.78 & 1.50 & 6.45 & 10.19 \\
\hline San Jose & 4.60 & 0.86 & 3.82 & 6.23 \\
\hline Santa Barbara & 8.71 & 1.68 & 7.15 & 11.73 \\
\hline Santa Cruz & 6.69 & 1.59 & 5.14 & 9.17 \\
\hline Santa Monica & 11.46 & 1.46 & 9.87 & 14.46 \\
\hline Stockton & 3.19 & 0.61 & 2.57 & 4.45 \\
\hline Turlock & 3.36 & 0.53 & 2.97 & 4.44 \\
\hline Victorville & 2.59 & 0.29 & 2.26 & 3.03 \\
\hline Visalia & 3.58 & 0.23 & 3.26 & 3.97 \\
\hline Vista & 4.29 & 0.61 & 3.71 & 5.69 \\
\hline & & & & \\
\hline
\end{tabular}


Table 3: Effects of Unaffordable Housing on City Employment Growth in California, 1993-2004

(Dependent variable: employment growth in a California city over two years)

\begin{tabular}{|c|c|c|c|}
\hline & \multicolumn{3}{|c|}{ OLS Regressions } \\
\hline & \multicolumn{2}{|l|}{ (1) } & (2) \\
\hline Affordability ratio & \multicolumn{2}{|l|}{$\begin{array}{l}-0.003 \\
(0.002) \\
\end{array}$} & $\begin{array}{c}-0.025^{* * *} \\
(0.008)\end{array}$ \\
\hline Controls & \multicolumn{2}{|l|}{ Yes } & Yes \\
\hline Year fixed effects & \multicolumn{2}{|l|}{ Yes } & Yes \\
\hline City fixed effects & \multicolumn{2}{|l|}{ No } & Yes \\
\hline $\mathbf{R}^{2}$ & \multicolumn{2}{|l|}{0.10} & 0.31 \\
\hline \multirow{3}{*}{ No. of observations } & \multirow{2}{*}{\multicolumn{3}{|c|}{ 2SLS Regressions }} \\
\hline & & & \\
\hline & $\begin{array}{c}(1) \\
\text { IV: } \\
\text { jul_max×elect_price }\end{array}$ & $\begin{array}{c}(2) \\
\text { IV: } \\
\text { jan_min } \times \text { elect_price }\end{array}$ & $\begin{array}{c}\text { (3) } \\
\text { IV: } \\
\text { jul_max } \times \text { elect_price } \\
\& \\
\text { jan_min } \times \text { elect_price }\end{array}$ \\
\hline Affordability ratio & $\begin{array}{c}-0.012^{* *} \\
(0.005) \\
{[0.005]} \\
\{0.006\}\end{array}$ & $\begin{array}{c}-0.019 * * * \\
(0.007) \\
{[0.006]} \\
\{0.009\}\end{array}$ & $\begin{array}{c}-0.015^{* * *} \\
(0.005) \\
{[0.004]} \\
\{0.006\}\end{array}$ \\
\hline Controls & Yes & Yes & Yes \\
\hline Year fixed effects & Yes & Yes & Yes \\
\hline City fixed effects & No & No & No \\
\hline First-stage F-statistic & 38.35 & 15.70 & 22.68 \\
\hline $\begin{array}{l}\text { Hansen's J test p- } \\
\text { value }\end{array}$ & - & - & 0.319 \\
\hline $\begin{array}{l}\text { Endogeneity test } \\
\text { p-value }\end{array}$ & 0.083 & 0.035 & 0.027 \\
\hline No. of observations & 902 & 903 & 870 \\
\hline
\end{tabular}

Note: Standard errors clustered by county are in parentheses.

For the IV results, alternative standard errors are also reported. Standard errors clustered by county-year are in square brackets. Standard errors clustered by city are in curly brackets.

Levels of significance: ${ }^{*} \mathrm{p}<0.10,{ }^{* *} \mathrm{p}<0.05,{ }^{* * *} \mathrm{p}<0.01$.

Levels of significance, first-stage F-statistics, Hansen’s J tests, and endogeneity tests are all based on standard errors clustered by county.

Although not reported in this table, we included an intercept and controlled for log city population and the percentage of adult population in the city with a bachelor's degree in all specifications. 
Table 4: Effects of Unaffordable Housing on City Employment Growth in California, 1993-2004: Alternative Specifications

(Dependent variable: employment growth in a California city over two years)

\begin{tabular}{|c|c|c|c|}
\hline & \multicolumn{3}{|c|}{$\begin{array}{c}\text { A. IV results on CA city employment growth, specification with coastal } \\
\text { dummy }\end{array}$} \\
\hline & IV: jul_max×elect_price & $\begin{array}{c}\text { IV: } \\
\text { jan_min } \times \text { elect_price }\end{array}$ & $\begin{array}{l}\text { IV: jul_max } \times \text { elect_price } \\
\& \text { jan_min } \times \text { elect_price }\end{array}$ \\
\hline Affordability ratio & $\begin{array}{c}-0.011 \\
(0.011)\end{array}$ & $\begin{array}{c}-0.024 * * \\
(0.011) \\
\end{array}$ & $\begin{array}{c}-0.016^{* *} \\
(0.008)\end{array}$ \\
\hline First-stage F-statistic & 15.56 & 5.62 & 9.80 \\
\hline \multirow[t]{3}{*}{ No. of observations } & 902 & 903 & 870 \\
\hline & \multicolumn{3}{|c|}{$\begin{array}{l}\text { B. IV results on CA city employment growth, specification with } \\
\text { additional controls }\end{array}$} \\
\hline & IV: jul_max $\times$ elect_price & $\begin{array}{c}\text { IV: } \\
\text { jan_min } \times \text { elect_price }\end{array}$ & $\begin{array}{l}\text { IV: jul_max } \times \text { elect_price } \\
\& \text { jan_min } \times \text { elect_price }\end{array}$ \\
\hline Affordability ratio & $\begin{array}{r}-0.012^{*} \\
(0.006) \\
\end{array}$ & $\begin{array}{c}-0.022^{* * *} \\
(0.007) \\
\end{array}$ & $\begin{array}{c}-0.016^{* *} \\
(0.006)\end{array}$ \\
\hline First-stage F-statistic & 30.53 & 28.52 & 12.07 \\
\hline No. of observations & 639 & 634 & 613 \\
\hline
\end{tabular}

Note: Standard errors clustered by county are in parentheses.

Levels of significance: ${ }^{*} \mathrm{p}<0.10,{ }^{* *} \mathrm{p}<0.05,{ }^{* * *} \mathrm{p}<0.01$.

Levels of significance and first-stage F-statistics are based on standard errors clustered by county.

Although not reported in this table, in all regressions, we included an intercept and controlled for the year fixed effect, log city population, and the percentage of adult population in the city with a bachelor's degree in all specifications. In addition, in panel B, we also controlled for per capita government general expenditure; share of government expenditure spent on road, fire protection, and police; retail and wholesale employment as a share of total employment; manufacturing employment as a share of total employment; and violent crime rate. 